\title{
Biotechnology and production-related hormones
}

\section{By I. C. HART*, Coopers Animal Health Ltd, Berkhamsted Hill, Berkhamsted, Herts HP4 2QE}

Although steroid and easily-synthesized hormones have been used to manipulate farm-animal growth and reproduction for several years, endocrinologists investigating the role of polypeptide hormones in these contexts have long been frustrated by the lack of sufficient material to thoroughly examine the possibility that such hormones might enhance production on a commercial scale. However, the last 7 years have witnessed the rapid development of techniques which have added new dimensions to the possibility of using polypeptide hormones to improve animal growth, lactation and reproduction. Most important among these is the application of recombinant-DNA technology to the biosynthetic production of purified protein hormones from prokaryotic, and possibly eukaryotic, cells. Recent advances in the same area have shown that it is possible to control endogenous hormone secretion by the direct transfer of the appropriate cloned genes (transgenic) to early embryos. Furthermore, site-directed mutagenesis and the specificity of monoclonal antibodies offer two methods for manipulating and directing hormonal activity towards a specified purpose.

Recombinant-DNA-derived human insulin and human growth hormone (hGH) are already being marketed for controlling diabetes mellitus and the treatment of hypopituitary children respectively. The application of biotechnology to animal production centres almost exclusively on growth hormone (GH) but a certain amount of work is being carried out with the insulin-like growth factors (somatomedins) and epidermal growth factor.

\section{$G H$}

Recombinant-DNA-derived GH. There is insufficient space here for a detailed description of the molecular genetic techniques employed in the production of the different recombinant-DNA-derived GHs. The basic principles are described in reviews (Miozzari, 1981; Miller \& Eberhardt, 1983; Wallis et al. 1985) but the detail often varies and much of the technology remains unpublished as it is of commercial value.

Cloning of cDNA produced from the mRNA for rat GH (rGH) was first carried out in 1977 (Seeburg et al. 1977) and expression was subsequently achieved by transferring it to a plasmid in which it was under the control of the $\beta$-lactamase $(E C$ 3.5.2.6) gene. When reinserted into Escherichia coli the expression plasmid directed the production of a fusion protein which cross-reacted immunologically with antibodies to rGH (Seeburg et al. 1978). Recombinant-DNA-derived human $\mathrm{GH}$ (rehGH) was initially produced by a method similar to that described for rGH (Martial et al. 1979) but this was superceded by a technique involving the covalent linkage of a synthetic DNA sequence (coding for hGH 1-23) to a cDNA fragment known to include the coding sequence for hGH 24-191 (Goeddel et al. 1979). A 'hybrid' gene was thus constructed which, when inserted into a plasmid under the control of lac operon (Fig. 1) and grown in a suitable strain of $E$. coli, produced an encouraging yield of hormone.

*Present address: American Cyanamid Co., Agricultural Research Division, PO Box 400, Princeton, New Jersey 08540 , USA. 


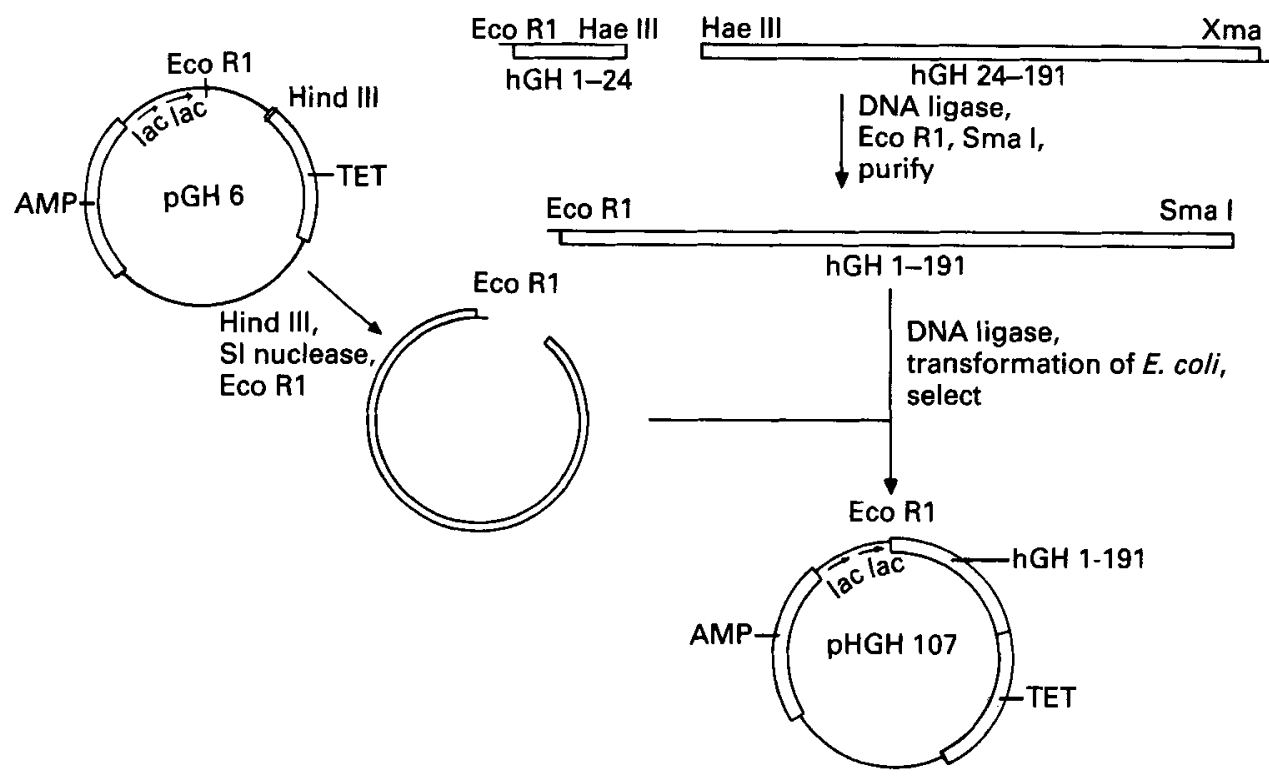

Fig. 1. Scheme showing the procedure used to produce a plasmid that would give rise to expression of human growth hormone $(\mathrm{hGH})$ in $E$. coli. A synthetic deoxynucleotide corresponding to the first twenty-four residues of $h \mathrm{hH}$ was combined with a restriction fragment of cDNA corresponding to the remainder of the molecule. The complete sequence was inserted into an expression plasmid (pGH 6) so as to be under the control of tandem lac promoters, leading to an efficient expression of hGH (from Wallis et al. 1985, based in part on Goeddel et al. 1979).

Miller et al. (1980) first reported the molecular cloning of DNA complementary to the mRNA of bovine GH (bGH) and this was followed by the publication of a method describing the insertion of a hybrid plasmid in E. coli and the expression of a fused $\beta$-lactamase-bGH protein (Keshet et al. 1981). The cloning and expression of recombinant-DNA-derived chicken GH (recGH) has been described by Souza et al. (1984).

In order to express the mature form of GH in $E$. coli the gene is usually modified such that the first amino acid(s) of the recombinant hormone do not correspond with that of the natural hormone. This is necessitated by the fact that, unlike eukaryotic cells, bacteria do not have the appropriate mechanism to cleave the leader peptide. Thus, the least-modified forms of the recombinant hormone have either an additional amino acid (often methionine) at the $\mathrm{N}$-terminus or a different amino acid substituted for the normal $\mathrm{N}$-terminal residue. This raised the question of whether the biological activity of the recombinant GH differed from that of the pituitary hormone. Such a comparison was of additional interest as it had been suggested that the various biological activities of GH were mediated by either pituitary contaminants or heterogeneous forms of the pituitaryderived hormone (for references, see Hart et al. 1984). A number of studies have been completed with hGH and it is recognized that the pituitary and recombinant hormones are identical with respect to growth-promoting activity (Stebbing et al. 1981), diabetogenic activity (Rosenfeld $e$ t al. 1982) and early insulin-like activity (Schwartz \& Foster, 1986). A similar situation exists with respect to recombinant-DNA-derived bovine GH (rebGH) (Hart et al. 1984) and recGH (Souza et al. 1984). However, there is some disagreement as to whether the recombinant-DNA-derived hormones possess intrinsic lipolytic activity (Frigeri et al. 1982; Goodman, 1984; Hart et al. 1984; Campbell \& Scanes, 1985). 
Recombinant-DNA-derived $G H$ and animal production. The role of $\mathrm{GH}$ in maintaining and enhancing farm-animal growth and lactation has recently been comprehensively reviewed (Bauman \& McCutcheon, 1985; Hart \& Johnsson, 1986; Johnsson \& Hart, 1987).

(a) Milk production. It has been known for some years that GH is essential for the maintenance of ruminant lactation (see Cowie \& Tindal, 1971) and that plasma concentrations of the hormone are positively correlated with milk yield in lactating cows (Hart et al. 1979). Furthermore, circulating levels of GH are higher in high-yielding (Friesian) as compared with low-yielding (Hereford $\times$ Friesian) cows (Hart et al. 1978) and this difference is closely related to the different metabolic status of the two groups (Hart, 1983). The galactopoietic properties of exogenous GH have been recognized since the 1930s but the scarcity of the pituitary hormone ensured that the subject was only studied intermittently over subsequent decades. However, since 1979 the potential production of commercial quantities of the recombinant-DNA-derived hormone has stimulated a resurgence of interest but it is significant that the majority of these recently published experiments have been conducted with pituitary-derived $\mathrm{GH}$ (for references, see Johnsson \& Hart, 1987).

A compilation of these findings indicates that the proportional effect of short-term treatment with bGH on milk production increases as lactation advances such that a $20-40 \%$ improvement can be expected in late lactation. The minimum effective dose lies between 5 and $10 \mathrm{mg} / \mathrm{d}$ and there is a pattern of declining marginal returns to increasing doses of bGH beyond $20 \mathrm{mg} / \mathrm{d}$. The increase in yield takes at least $7 \mathrm{~d}$ to become established and the response is maintained for the duration of the treatment, declining to predicted, unstimulated levels at the cessation of treatment. The effects of bGH on milk composition are small in comparison with the marked changes in the total output of milk constituents. However, the hormone often stimulates an increase in the concentration of milk fat and a slight reduction in milk protein under the conditions of energy deficit or the use of very-high doses of bGH, or both (Bines et al. 1980; Peel et al. 1981; Eppard et al. 1985). Short-term treatment with the hormone is often associated with reduced food intake, particularly in late lactation (Bines et al. 1980; Peel et al. 1983).

The mechanism(s) by which GH exerts its effect on established lactation remain to be defined. Current theories suggest either a direct or indirect (e.g. via the somatomedins) effect of the hormone on the mammary gland; repartitioning of nutrients away from tissue deposition towards mammary utilization or by increasing blood flow thereby increasing the supply of substrates to the gland (for discussion, see Johnsson \& Hart, 1987).

Bauman et al. (1982) were the first to publish a comparison of pituitary bGH and rebGH $(25 \mathrm{mg} / \mathrm{d})$ on milk production by cows throughout a $6 \mathrm{~d}$ period. They observed similar increases in milk yield $(10.3$ and $12.9 \%$ respectively) and food conversion efficiency ( 9.5 and $15.2 \%$ respectively) and concluded that the production response to rebGH did not differ from that of the pituitary hormone. However, this conclusion was not supported by a second, long-term study in which the same group (Bauman et al. $1985)$ compared the effect of injecting three doses of rebGH $(13.5,27.0$ and $40.5 \mathrm{mg} / \mathrm{d})$ and one dose of pituitary bGH $(27.0 \mathrm{mg} / \mathrm{d})$ on the milk produced by groups of six cows starting at 84 (SE 10) d of lactation and continuing for $188 \mathrm{~d}$. The milk yields are shown in Fig. 2 and Table 1. Cows receiving the two higher doses of rebGH increased their milk production to a level in excess of that previously achieved at peak lactation and maintained the yield at greater than pretreatment values for over $100 \mathrm{~d}$. However, treatment with pituitary bGH stimulated a sharp increase in milk production but the yield then declined more rapidly than did that of the cows receiving the equivalent dose 


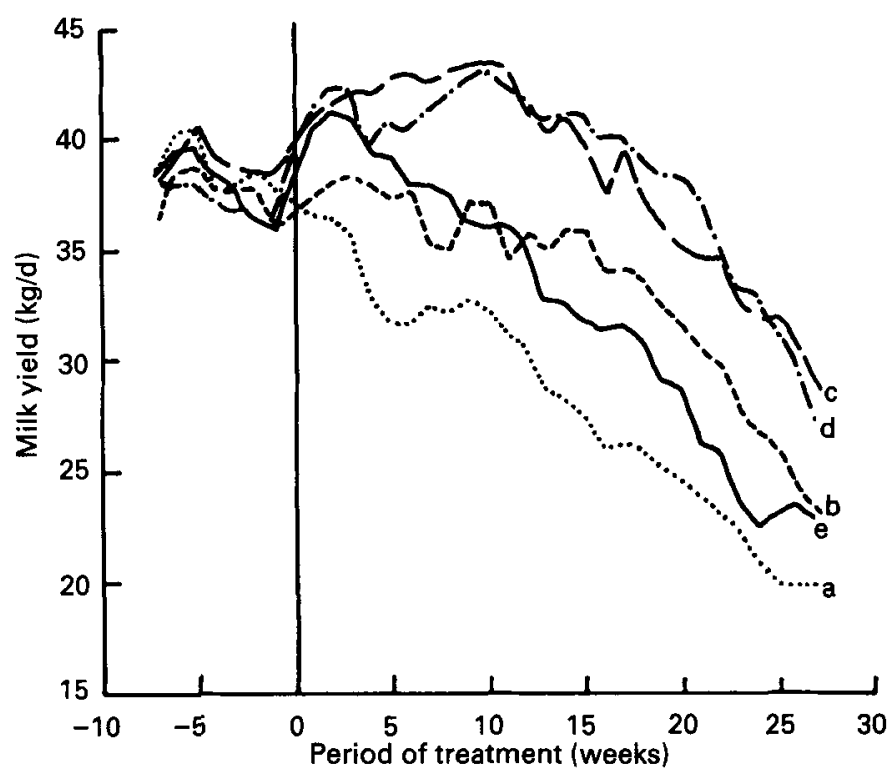

Fig. 2. Effect of exogenous pituitary bovine growth hormone (bGH) and recombinant-DNA-derived bovine growth hormone (rebGH) on milk yield of groups of six cows. Treatment commenced at week 0 (84 (SE 10) d post partum) and continued for 27 weeks. Milk production values represent weekly averages. (a), Control; (b), $13.5 \mathrm{mg}$ rebGH; (c), $27.0 \mathrm{mg}$ rebGH; (d), $40.5 \mathrm{mg}$ rebGH; (e), $27.0 \mathrm{mg}$ pituitary bGH (from Bauman et al. 1985).

of the recombinant hormone. Thus, there was a significant difference in the overall milk yield responses to the pituitary $(+16 \cdot 5 \%)$ and recombinant $(+36 \cdot 2 \%)$ hormones (Table 1).

Net energy intake was similar for all groups during the first 5 weeks but, after 9-11 weeks of treatment, the cows receiving the two highest doses of rebGH were consuming significantly more food and this divergence increased as the experiment continued. The energy balance of all the GH-injected groups declined immediately after the start of treatment but only two groups (27.0 mg pituitary bGH/d, $40.5 \mathrm{mg} \mathrm{rebGH/d}$ ) achieved negative energy status. The increased food intake ensured that all the animals were in positive energy balance by week 10 of treatment. When gross lactational efficiency was

Table 1. Effect of exogenous growth hormone (GH) on yield and composition of milk from six cows (from Bauman et al. 1985)

\begin{tabular}{|c|c|c|c|c|c|}
\hline \multirow[b]{2}{*}{ Variable $\dagger$} & \multirow[b]{2}{*}{ Control } & \multirow{2}{*}{$\begin{array}{c}\text { Pituitary } \\
\text { bGH } \\
(27.0 \mathrm{mg} / \mathrm{d})\end{array}$} & \multicolumn{3}{|c|}{ rebGH $(\mathrm{mg} / \mathrm{d})$} \\
\hline & & & $13 \cdot 5$ & $27 \cdot 0$ & $40 \cdot 5$ \\
\hline $\mathrm{FCM}(\mathrm{kg} / \mathrm{d})$ & $27 \cdot 9^{\mathrm{a}}$ & $32 \cdot 5^{a, b}$ & $34 \cdot 4^{b, c}$ & $38.0^{\mathrm{c}}$ & $39.4^{\mathrm{c}}$ \\
\hline Milk fat $(\mathrm{g} / \mathrm{kg})$ & 36 & 33 & 38 & 36 & 36 \\
\hline Milk protein $(\mathrm{g} / \mathrm{kg})$ & 34 & 34 & 34 & 34 & 34 \\
\hline Milk lactose $(\mathrm{g} / \mathrm{kg})$ & 48 & 48 & 49 & 48 & 49 \\
\hline
\end{tabular}

bGh, bovine GH; rebGH, recombinant-DNA-derived bGH; FCM, $3.5 \%$ fat-corrected milk.

$a, b, c$ Mean values in the same row with different superscript letters differed significantly $(P<0.05)$.

$\nmid$ Response values (weekly means) were adjusted by covariance analysis using each individual cow's response during the excipient period. 
expressed as $\mathrm{kg} \mathrm{3.5 \%} \mathrm{fat-corrected} \mathrm{milk/Mcal} \mathrm{net} \mathrm{energy} \mathrm{there} \mathrm{was} \mathrm{a} \mathrm{dose-dependent}$ increase in the ratio which was significantly greater for the two higher doses of rebGH. The dose response was removed when corrections were made for changes in body-weight but the overall improvement in production efficiency was maintained for the rebGHtreated groups.

Although the most profitable application of recombinant $\mathrm{GH}$ is in dairy cows, Harkins et al. (1986) have shown that recombinant-DNA-derived porcine GH (repGH; 8.22 $\mathrm{mg} / \mathrm{d}$ ) will stimulate milk production in sows with a corresponding, non-significant, improvement in the weight gain of the piglets. However, hormone treatment appeared to inhibit food intake thus resulting in greater losses in sow weight and backfat when compared with controls.

It has been suggested that hormonally stimulating cows to increase milk production may result in an increased incidence of subclinical ketosis which might lead to decreased resistance to disease and reproductive inefficiency (Kronfeld \& Chalupa, 1986). As yet there is no evidence to support this contention.

(b) Meat production. The stimulatory effects of exogenous pituitary-derived GH on the growth of farm animals have been less consistent than that on milk production. A number of studies reported relatively mediocre responses for the treatment of pigs with pGH but Machlin (1972) established that daily injection of pGH could stimulate live-weight gain by up to $16 \%$, increase food conversion efficiency by $19 \%$ and markedly improve carcass composition in rapidly growing pigs. These findings have been largely supported by a recent abstract by Rebhun et al. (1985).

A similar situation exists for ruminants. Wagner \& Veeinhuizen (1978) treated a small number of relatively mature lambs with ovine $\mathrm{GH}(\mathrm{oGH})$ and suggested that the hormone had considerable potential as an anabolic agent, but this view was not shared by Muir et al. (1983). More recently, Johnsson et al. (1985) treated a larger number of lambs with bGH (0.1 mg/kg per d) for 12 weeks between 17 and $47 \mathrm{~kg}$ body-weight and obtained significant increases in live-weight gain $(+22 \%)$, food conversion efficiency $(+12 \%)$ and carcass lean meat $(+24 \%)$. These findings have since been confirmed (Wolfrom et al. 1986) and the effects of bGH and the anabolic agent Ralgro (zeranol) have been shown to be additive. Until recently, the only two published reports on the effects of giving exogenous pituitary bGH to growing cattle indicated that the hormone stimulated only a modest non-significant increase (10-13\%) in live-weight gain. However, abstracts emanating from the August 1985 meeting of the American Society of Animal Science claim that the pituitary hormone can promote substantial improvements in the rate of gain and food conversion efficiency in cattle (Fabry et al. 1985; Wolfrom \& Ivy, 1985).

The application of recombinant-DNA-derived GH to stimulate growth in farm species was first examined by Baile et al. (1983) who treated pigs, between 23 and $90 \mathrm{~kg}$ body-weight, with three doses $(0.015,0.03$ and $0.06 \mathrm{mg} / \mathrm{kg}$ per d) of rehGH. The lowest dose increased average daily gain $(0.89 v .0 .82 \mathrm{~kg} ; P<0.05)$ and food intake $(4.59 v .4 .25$; $P<0.006)$ but there was no improvement in food conversion efficiency or carcass quality.

Two abstracts have been published in which the same group examined the use of rebGH in growing lambs and obtained different results in the two experiments. In the first (Johnsson et al. 1986) rebGH was administered (between 10 and 21 weeks of age) either by daily subcutaneous injection in buffer $(0.025,0.1$ and $0.25 \mathrm{mg} / \mathrm{kg}$ per d), daily subcutaneous injection in oil $(0.1 \mathrm{mg} / \mathrm{kg}$ per $\mathrm{d})$ or constant infusion $(0.1 \mathrm{mg} / \mathrm{kg}$ per d). Although the recombinant hormone stimulated a significant reduction in carcass fat and increased wool growth, it had little or no effect on live weight, food intake or food conversion efficiency. However, in the second study (Pullar et al. 1986), which was 
Table 2. Dose responses in Dorset ram lambs given daily subcutaneous injections of recombinant-DNA-derived bovine growth hormone (rebGH) for 6 weeks (from Pullar et al. 1986)

(Mean values with their standard errors; number of lambs in parentheses)

Initial live wt $(\mathrm{kg})$

Final live wt $(\mathrm{kg})$

Live-wt gain (g/d)

Cold carcass wt $(\mathbf{k g})$

Chemical carcass fat $(\mathrm{g} / \mathrm{kg} \mathrm{DM})$

Chemical carcass protein $(\mathrm{g} / \mathrm{kg} \mathrm{DM})$

\begin{tabular}{|c|c|c|c|c|}
\hline \multicolumn{4}{|c|}{ Treatment } & \multirow{3}{*}{ Change $\%$} \\
\hline \multicolumn{2}{|c|}{ Control (n 6) } & \multicolumn{2}{|c|}{ rebGH $(n 4)$} & \\
\hline Mean & SE & Mean & SE & \\
\hline $23 \cdot 8$ & 1.22 & $26 \cdot 3$ & 3.55 & $+8 \cdot 0$ \\
\hline $32 \cdot 7$ & $1 \cdot 3$ & $37 \cdot 3$ & $2 \cdot 2$ & $+14 \cdot 0^{*}$ \\
\hline 242 & $10 \cdot 2$ & 315 & $30 \cdot 4$ & $+30 \cdot 0^{*}$ \\
\hline $16 \cdot 3$ & 0.61 & $18 \cdot 3$ & $1 \cdot 3$ & $+12 \cdot 0$ \\
\hline 421 & $2 \cdot 9$ & 429 & $2 \cdot 3$ & $+4 \cdot 7$ \\
\hline 440 & $2 \cdot 2$ & 446 & $2 \cdot 7$ & +1.4 \\
\hline
\end{tabular}

primarily designed to examine the effect of the recombinant hormone on the lipolytic and lipogenic activity of adipose tissue, the daily subcutaneous injection of rebGH $(0 \cdot 1$ $\mathrm{mg} / \mathrm{kg}$ per d) between 12 and 18 weeks of age, stimulated a significant improvement $(30 \%)$ in the growth rate of ram lambs (Table 2). Quite obviously other factors influence the presence or absence of a growth response to GH treatment and these require elucidation before an increase in growth rate can be confidently expected in ruminants.

Perhaps the most unusual application of recombinant-DNA-derived GH has been the use of heterologous forms of the hormone to enhance salmon production. Intraperitoneal injection of recGH and rebGH $(5 \mu \mathrm{g} / \mathrm{g}$ per week) over a $42 \mathrm{~d}$ period stimulated a doubling of growth rate and a significant increase in food conversion efficiency (Gill et al. 1985).

(c) Modified forms of $\mathrm{GH}$. The physiology of $\mathrm{GH}$ has been closely studied for over 50 years and it is now accepted that the hormone either directly or indirectly influences several metabolic processes. For example, it is anabolic, stimulating cell division, skeletal growth and protein synthesis (growth-promoting activity); it increases the oxidation of fat (lipolytic activity); it inhibits glucose transport into body tissues (diabetogenic activity) and hGH is uniquely lactogenic. It has been suggested that, under certain circumstances relating to animal production, it might be desirable to manipulate the structure of the hormone in such a manner that a given activity is enhanced whilst one or more functions of the hormone are removed (for discussion, see Hart \& Johnsson, 1986). Recombinant-DNA technology facilitates this approach as the sequence of the DNA coding for the hormone can simply be altered, by site-directed mutagenesis, before its insertion and expression in the host bacterium.

A modified analogue of hGH has already been prepared by this method (Gertler et al. 1986), which lacked the first thirteen amino acids at the amino terminus (Met ${ }^{14} \mathrm{hGH}$ ) and has been shown to inhibit the lactogenic activities of hGH and ovine and bovine prolactin in vitro. The analogue appeared to act as an antagonist as the inhibition was competitive in nature. As yet, there is no information on its biological activities.

(d) Monoclonal antibody enhancement of GH activity. Advances in another sphere of biotechnology have presented an alternative method of modifying the biological activity of polypeptide hormones. There is a widely held opinion that antibodies raised against a 


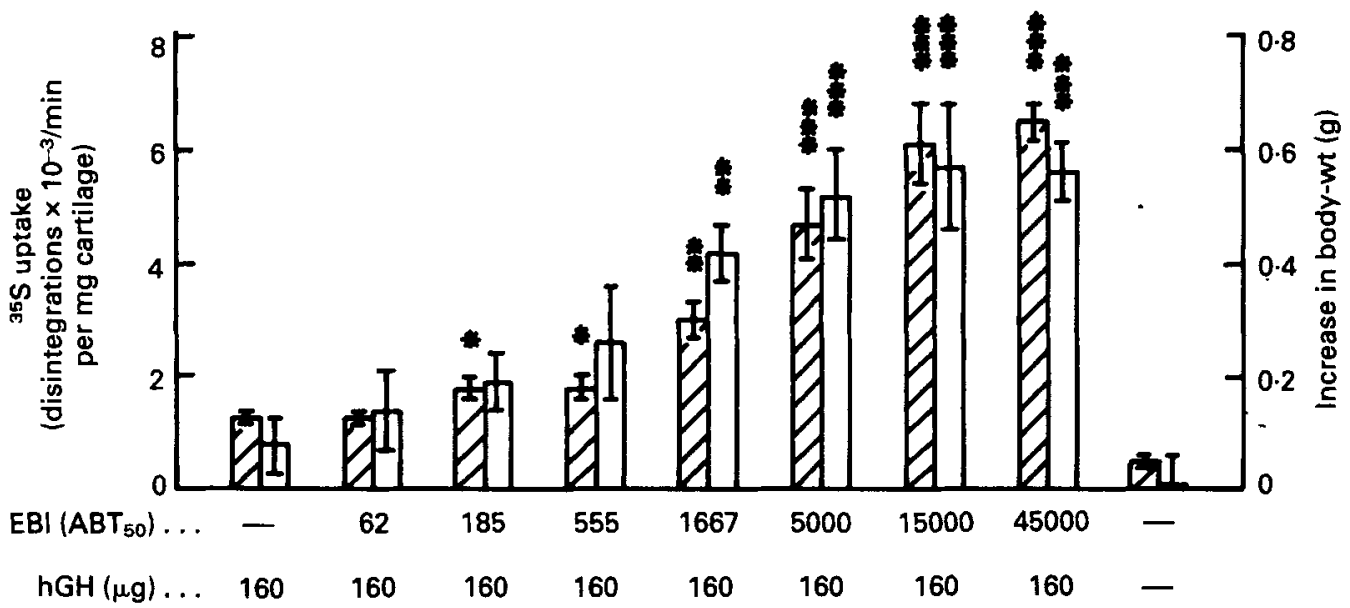

Fig. 3. The effect of various doses of monoclonal antibody (EBI; $62-45000 \mathrm{ABT}_{50} / \mathrm{d}$ for $2 \mathrm{~d}$ ) complexed with a constant dose of human growth hormone (hGH; $160 \mu \mathrm{g} / \mathrm{d})$ on uptake of ${ }^{35} \mathrm{SO}_{4}{ }^{2-}\left({ }^{35} \mathrm{~S}\right)$ into dwarf mouse costal cartilage in vivo $(\square)$ and increase in body-weight $(\square)$. Control animals were injected with phosphatebuffered saline $(9 \mathrm{~g}$ sodium chloride $/$ ). Values are means with their standard errors represented by vertical bars. When compared with hGH alone, values were significantly different: ${ }^{*} P<0.05,{ }^{* *} P<0 \cdot 01,{ }^{* * *} P<0.001$ (from Holder et al. 1985).

EBI, a monoclonal antibody which binds to antigenic determinants on both hGH and human chronic somatomammotrophin; $\mathrm{ABT}_{50}$, value which corresponds to the dilution (titre) of monoclonal antibody required to find $50 \%$ of the tracer $\left[{ }^{125} \mathrm{~T}\right] \mathrm{hGH}$ in a liquid-phase radioimmunoassay.

given hormone will inhibit its biological activity. Although this is largely true for polyclonal antibodies, it is not the case for monoclonal antibodies (MAB) which are specific for only a short amino acid sequence of the molecule. It has recently been shown that certain MAB raised against $\mathrm{hGH}$ and oGH can markedly increase the growthpromoting activity of their respective hormones when complexed in vitro and examined in terms of ${ }^{35} \mathrm{SO}_{4}{ }^{2-}$ uptake into the costal cartilage of dwarf and normal mice (Fig. 3; Holder et al. 1985; Aston et al. 1986, 1987). The same MAB-GH complexes have stimulated an increase in the growth rates of mice and rats with a corresponding reduction in carcass fat and an improved food conversion efficiency (Fig. 3; Holder $e$ t al. 1985; R. Aston, personal communication). However, of greater significance was the fact that Holder $e t$ al. (1985) were able to potentiate the growth-promoting activity of endogenous physiological concentrations of GH by directly administering MAB (raised against hGH which cross-reacts with monkey $\mathrm{GH}$ ) to young, normal marmoset monkeys and measure a significant rise in growth rate.

Aston et al. $(1986,1987)$ have systematically examined the mechanism by which MAB potentiate the activity of GH in terms of specificity, the rate of hGH-MAB clearance from the circulation and the possible contribution of bivalency-dependent mechanisms. They have tentatively suggested that the enhanced activity is a result of the MAB restricting the binding of the hormone to somatogenic receptors.

Experiments have shown that passive immunization with a MAB specific for an epitope on the oGH molecule enhances both the diabetogenic (measured by insulintolerance tests) and milk-stimulating activity of both endogenous and exogenous $\mathrm{GH}$ in sheep (I. D. Johnsson, R. A. Pullar, I. C. Hart, J. M. Pell and R. Aston, unpublished results). This is the first indication that this approach can be used to modify the metabolic activity and increase the production potential of GH in a farm species. Although the 
Table 3. Metallothionein-I-growth hormone fusion genes (MGH), MGH-mRNA, growth hormone levels and growth of transgenic mice (from Palmiter et al. 1982)

\begin{tabular}{|c|c|c|c|c|c|c|}
\hline Mouse & Sex & $\begin{array}{l}\text { No. of MGH } \\
\text { genes/cell }\end{array}$ & $\begin{array}{l}\text { No. of MGH-mRNA } \\
\text { molecules/cell }\end{array}$ & $\begin{array}{c}\text { Growth } \\
\text { hormone }(\mu \mathrm{g} / \mathrm{ml})\end{array}$ & \multicolumn{2}{|c|}{$\begin{array}{l}\text { Growth* } \\
\text { (g) }\end{array}$} \\
\hline MGH2 & Q & 20 & 800 & 57.0 & \multicolumn{2}{|c|}{41.2} \\
\hline MGH3 & † & 1 & $<50$ & 0.87 & \multicolumn{2}{|c|}{22.5} \\
\hline MGH10 & $\sigma^{+}$ & 8 & $<50$ & 0.28 & \multicolumn{2}{|c|}{34.4} \\
\hline MGH14 & $\sigma^{\pi}$ & 2 & $<50$ & 0.31 & \multicolumn{2}{|c|}{30.6} \\
\hline MGH16 & $\sigma^{\prime \prime}$ & 2 & $<50$ & 17.9 & \multicolumn{2}{|c|}{36.4} \\
\hline MGH19 & $0^{\pi}$ & 10 & 1500 & 32.0 & \multicolumn{2}{|c|}{44.0} \\
\hline MGH21 & $\overline{0}$ & 35 & 3000 & 112.0 & \multicolumn{2}{|c|}{39.3} \\
\hline & & & & & Mean & SE \\
\hline \multirow{2}{*}{\multicolumn{2}{|c|}{ (n 3) }} & 0 & 0 & $0 \cdot 16$ & $22 \cdot 00$ & 0.8 \\
\hline & & & & & & \\
\hline \multicolumn{2}{|c|}{$(n 11)$} & 0 & 0 & $0 \cdot 15$ & $26 \cdot 0$ & $2 \cdot 0$ \\
\hline
\end{tabular}

current cost of mass-producing MAB precludes their commercial use for stimulating growth and lactation, this more specific immunological manipulation of endogenous hormone activity has introduced a new concept which is likely to find application in the future.

(e) Gene transfer and enhanced GH secretion. In addition to facilitating the bacterial production of $\mathrm{GH}$, recombinant-DNA technology has provided an alternative method of increasing endogenous GH which involves the introduction of foreign DNA into the mammalian genome (Wagner et al. 1984; Wagner, 1985). The first successful incorporation of functional genes, coding for a variety of proteins, was accomplished by several laboratories between 1980 and 1981 (Wagner et al. 1984). By 1982 Palmiter et al. (1982) reported the micro-injection of a DNA fragment, containing the promoter of the mouse metallothionein-I gene fused to the structural gene of $\mathrm{rGH}$, into the pronuclei of fertilized mouse eggs. Seven out of the twenty-one mice that developed from those eggs carried the fusion genes (MGH genes) and six of these grew significantly faster than their litter-mates (Table 3). Furthermore, one of the mice (MGH 10) transmitted the MGH genes to ten of nineteen offspring, suggesting that the genes were incorporated into one of the chromosomes. Three of the mice (MGH 2, 19 and 21), showing the highest growth rates, had high levels of MGH-mRNA in their livers and very high concentrations of circulating GH. A different approach was adopted by Hammer et al. (1985a) in which they established strains of transgenic mice containing the mouse metallothionein gene fused to the hGH-releasing factor gene. The plasma of these mice contained elevated circulating levels of $\mathrm{GH}$-releasing factor and $\mathrm{GH}$ and they grew faster than controls.

The application of transgenic techniques to increasing endogenous $\mathrm{GH}$ in farm animals has not been without problems. The successful micro-injection and integration of the metallothionein-I-hGH gene into the pronuclei or nuclei of ova obtained from superovulated pigs and sheep has been reported but the integration efficiencies were considerably lower than those achieved with mice because of difficulties in visually locating the cellular components (Hammer et al. 1985b). However, this may eventually be overcome by the use of reteroviral vectors for carrying the genetic information into the ovum (Panganiban, 1985). Although elevated circulating levels of hGH were 
measured in eleven of eighteen transgenic pigs, there was no indication of increased growth rates. In fact, it has been stated that 'arthritis-like symptoms and other pathologies' were observed in high expressers (Radke \& Lagarias, 1986). This suggests that, even in meat-producing animals, the excessive, uncontrolled expression of transgenic GH may be undesirable, just as it would be in dairy cows where uninterrupted high levels of $\mathrm{GH}$, during both lactation and the dry period, might stimulate abnormal growth and development. Thus, before the farming community can take full advantage of transgenic techniques, mechanisms must be developed for controlling the time and extent of recombinant GH expression in farm animals. There is an indication that this may be possible by including 'enhancer' and 'regulator' DNA sequences within the GH gene (Wagner, 1985).

\section{Insulin-like growth factors}

Both of the characterized insulin-like growth factors, IGF-I (somatomedin-C) and IGF-II (multiplication stimulating activity), are single-chain peptides with intrachain disulphide bridges. IGF-I consists of seventy amino acid residues with a molecular weight (MW) of 7649 , and IGF-II has sixty-seven amino acids with a MW of 7471 . The physiological role of IGF-I and the extent to which it mediates the anabolic properties of GH are still the subject of debate (Hall \& Sara, 1983; Froesch et al. 1985) but in general the hormone is thought to stimulate cell division, cartilage growth and protein and fat synthesis.

Recombinant-DNA-derived IGFs. Reference to bacterially-synthesized IGF-I was first made by Schalch et al. (1984). The hormone was produced from a chemically synthesized gene and contained a threonine substitution for methionine at position 59 as well as an eight amino acid leader peptide at the amino terminus. Comparison of this analogue with natural IGF-I in a radioimmunoassay and a protein-binding assay revealed consistent differences between the two forms of the hormone which were probably the result of their different structures. A more detailed description of the cloning and expression of IGF-I has been provided by Buell et al. (1985) but there was no assessment of the hormone's activity.

Although partially purified preparations of extracted IGF were found to increase body length and the weight of Snell dwarf mice (van Buul \& van den Brande, 1979) in a manner similar to that found with $\mathrm{GH}$, it was not until 1982 that the growth-promoting effects of natural IGF-I and IGF-II were clearly demonstrated in vivo (Schoenle et al. 1982). When pure extracted IGF-I was infused, throughout a $6 \mathrm{~d}$ period, into hypophysectomized rats, there was a dose-dependent stimulation of body-weight, tibial epiphyseal width and $\left[{ }^{3} \mathrm{H}\right]$ thymidine incorporation into costal cartilage DNA. On a weight basis, IGF-II was far less potent. Recombinant-DNA-derived IGF-I has recently been shown to enhance pregnenolone, progesterone and oestradiol synthesis in granulosa cells isolated from pig ovaries (Veldhuis \& Demens, 1985) and to stimulate in vitro myoblast proliferation in a dose-dependent fashion (Kotts \& Baile, 1985), but an initial attempt to demonstrate the growth-promoting activity of the biosynthetic hormone (Met-IGF-I) in hypophysectomized rats has achieved only limited success which may have been related to the relative impurity of the hormone (Skottner et al. 1985).

Potential use in farm animals. There is no information available on the growthmilk-stimulating ability of IGF-I in farm animals but a significant amount of evidence suggests that the hormone may play a substantial role in ruminant growth and lactation. High circulating levels of IGF activity have been measured in fast-growing breeds of pigs and sheep and others have correlated plasma IGF activity with the rate of body-weight gain in sheep and bull calves (for references, see Hart \& Johnsson, 1986). The fact that 
circulating IGF-I is raised in GH-treated dairy cows (Davis et al. 1984), that the hormone stimulates DNA and milk synthesis in lactating bovine mammary tissue (Baumrucker, 1986) coupled with the detection of IGF-I and IGF-II receptors on mammary parenchyma (R. J. Collier, personal communication) has led some to speculate that IGF may, to some extent, mediate the stimulatory effect of $\mathrm{GH}$ on milk production.

However, the success of IGF-I as a commercial product may depend very largely on the extent to which its biological activity is influenced by serum protein binding. Both IGF-I and IGF-II circulate in association with two carrier proteins having MW of $\sim 50000$ and $\sim 150000$ respectively. Very little is known of the mechanism by which these proteins modulate IGF activity, but it is suspected that the 150000 complex (which may be under the control of $\mathrm{GH}$ ) may be precluded from the interstitial space and, in this way, the accessibility of IGF to various membrane receptors is controlled (Froesch $e t$ al. 1985). The implications of this mechanism have yet to be defined in the context of the potential use of IGF-I as a growth promotant.

\section{Epidermal growth factor}

Although epidermal growth factor (EGF) does not fall within the strict definition of a hormone directly stimulating animal production, there is increasing evidence that the recombinant-DNA-derived material could be used as a defleecing agent and thereby improve the overall efficiency of the wool industry.

EGF was first discovered in an extract of mouse submaxillary gland (Cohen, 1962) and is one of the best characterized mitogens. It is a single polypeptide chain of fifty-three amino acids (MW 6045) with two intrachain disulphide bonds and, like IGF-I, it is thought to circulate in association with a binding protein. Various forms of EGF have been shown to stimulate the growth of several different cell types, including fibroblasts, endothelial, smooth muscle and epithelial cells (for references, see Brown \& Blay, 1986). Although human EGF (urogastrone) was produced by recombinant-DNA technology in

Table 4. Effect of intravenous epidermal growth factor (EGF) infusion $(3 \mathrm{mg} / 24 \mathrm{~h})$ during day 0, on wool-fibre indices in one sheep (from McDonald et al. 1983)

(Mean values with their standard errors for fifty-four wool fibres)

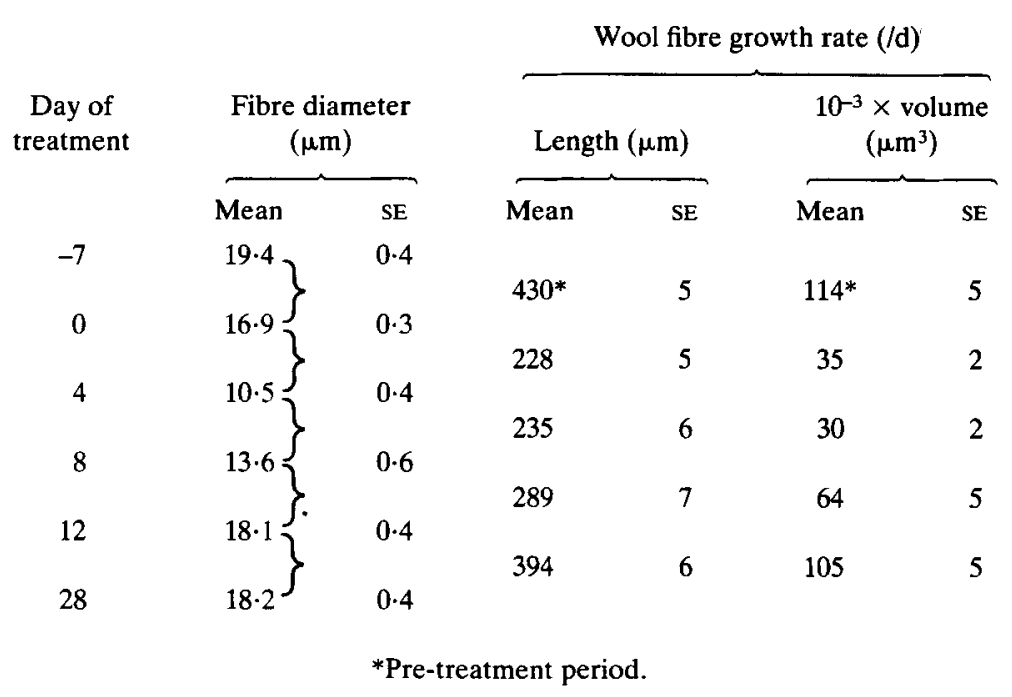


1982 (Smith et al. 1982), the early defleecing experiments were conducted with mouse EGF and the recombinant-DNA-derived form of this hormone has now been produced from a synthetic gene fused to part of a gene for a host protein and expressed at high levels in E. coli (Allen et al. 1985).

Moore et al. (1982) first investigated the effects of varying doses and modes of delivering extracted mouse EGF on wool growth and the incidence of breaks in the fleece of Merino whethers. Subcutaneous infusion of the hormone $(0.25 \mathrm{mg} / \mathrm{kg}$ for up to $28 \mathrm{~h})$ resulted in a dose-dependent total or partial inhibition of wool production 2-4 weeks later. A similar effect was later demonstrated by McDonald et al. (1983) who also showed that the infusion stimulated a sequence of changes in the wool fibres, their follicles and accessory structures (Table 4). The physiological mechanism(s) by which EGF inhibits wool growth have still to be defined and, as yet, there are no reports on the use of the recombinant hormone as a defleecing agent. Nonetheless, considerable work is being carried out in this area with a view to reducing the costs of production.

\section{Conclusion}

Pituitary GH has an established role in the growth and lactation of certain farm animals and, for that reason, the majority of biotechnological research has concentrated on the production and manipulation of that hormone. There seems little doubt that, barring political and welfare considerations, one or more of the approaches outlined in the present review will result in a commercial application. The utility of IGF, as a growth promotant, and EGF as a defleecing agent, has yet to be convincingly established. As for the future, there have been reports in the popular press of the cloning and expression of follicle-stimulating hormone (equine and porcine) and luteinizing hormone (equine) to improve the reproductive efficiency of horses and pigs but this has yet to achieve the respectability of scientific publication.

\section{REFERENCES}

Allen, G., Paynter, C. A. \& Winther, M. D. (1985). Journal of Cell Science, Suppl. 3, 29-38.

Aston, R., Holder, A. T., Ivanyi, J. \& Bomford, R. (1987). Molecular Immunology 24, 143-150.

Aston, R., Holder, A. T., Preece, M. A. \& Ivanyi, J. (1986). Journal of Endocrinology 110, 381-388.

Baile, C. A., Della-Fera, M. A. \& McLaughlin, C. L. (1983). Growth 47, 225-236.

Bauman, D. E., De Geeter, M. J., Peel, C. J., Lanza, G. M., Gorewit, R. C. \& Hammond, R. W. (1982). Journal of Dairy Science 65, Suppl. 1, 121 Abstr.

Bauman, D. E., Eppard, P. J., De Geeter, M. J. \& Lanza, G. M. (1985). Journal of Dairy Science 68, 1352-1362.

Bauman, D. E. \& McCutcheon, S. N. (1985). In Proceedings of the 6th International Symposium on Ruminant Physiology: Control of Digestion and Metabolism in Ruminants, chapt. 23 [L. P. Milligan, W. L. Grovum and A. Dobson, editors]. Reston: Reston Publishing Co. Inc.

Baumrucker, C. R. (1986). Journal of Dairy Science 69, Suppl. 1, 120 Abstr.

Bines, J. A., Hart, I. C. \& Morant, S. V. (1980). British Journal of Nutrition 43, 179-188.

Brown, K. D. \& Blay, J. (1986). In Control and Manipulation of Animal Growth. Proceedings of the University of Nottingham 43rd Easter School, 15-18 April 1985, pp. 119-134 [P. J. Buttery, N. B. Haynes and D. B. Lindsay, editors]. London: Butterworths.

Buell, G., Schulz, M. F., Slezer, G., Chollet, A., Movva, N. R., Semon, D., Escanez, S. \& Kawashima, E. (1985). Nucleic Acids Research 13, 1923-1938.

Campbell, R. M. \& Scanes, C. G. (1985). Proceedings of the Society for Experimental Biology and Medicine $180,513-517$.

Cohen, S. (1962). Journal of Biological Chemistry 237, 1555-1562.

Cowie, A. T. \& Tindal, J. S. (1971). The Physiology of Lactation, pp. 146-147. London: Edward Arnold.

Davis, S. R., Gluckman, P. D. \& Hart, I. C. (1984). Proceedings of the New Zealand Society of Endocrinology 75 Abstr. 
Eppard, P. J., Bauman, D. E. \& McCutcheon, S. N. (1985). Journal of Dairy Science 68, 1109-1115.

Fabry, J., Ruelle, L., Claes, V. \& Ettaib, E. (1985). Journal of Animal Science 61, Suppl. 1, 261-262.

Frigeri, L. G., Robel, G. \& Stebbing, N. (1982). Biochemical and Biophysical Research Communications 104, 1041-1046.

Froesch, E. R., Schmid, C., Schwander, J. \& Zapf, J. (1985). Annual Reviews of Physiology 47, 443-467.

Gertler, A., Shamay, A., Cohen, N., Ashkenazi, A., Friesen, H. G., Levanon, A., Gorecki, M., Aviv, H., Hadary, D. \& Vogel, T. (1986). Endocrinology 118, 720-726.

Gill, J. A., Sumpter, J. P., Donaldson, E. M., Dye, H. M., Souza, L., Berg, T., Wypych, J. \& Langley, K. (1985). Biotechnology 3, 643-646.

Goeddel, D. V., Heyneker, H. L., Hozumi, T., Arentzen, R., Itakura, K., Yansura, D. G., Ross, M. J., Miozzari, G., Crea, R. \& Seeburg, P. H. (1979). Nature 281, 544-548.

Goodman, H. M. (1984). Endocrinology 114, 131-135.

Hall, K. \& Sara, V. R. (1983). Vitamins and Hormones 40, 175-233.

Hammer, R. E., Brinster, R. L., Rosenfeld, R. G., Evans, R. M. \& Mayo, K. E. (1985a). Nature 315, 413-416.

Hammer, R. E., Pursel, V. G., Rexroad, C. E., Wall, R. J., Bolt, D. J., Ebert, K. M., Palmiter, R. D. \& Brinster, R. L. (1985b). Nature 315, 680-683.

Harkins, M., Boyd, R. D., Bauman, D. E. \& Butler, W. R. (1986). Journal of Animal Science 61, Suppl. 1, 316-317.

Hart, I. C. (1983). Proceedings of the Nutrition Society 42, 181-194.

Hart, I. C., Bines, J. A. \& Morant, S. V. (1979). Journal of Dairy Science 62, 270-277.

Hart, I. C., Bines, J. A., Morant, S. V. \& Ridley, J. L. (1978). Journal of Endocrinology 77, 333-345.

Hart, I. C., Chadwick, P. M. E., Boone, T. C., Langley, K. E., Rudman, C. \& Souza, L. (1984). Biochemical Journal 224, 93-100.

Hart, I. C. \& Johnsson, I. D. (1986). In Control and Manipulation of Animal Growth. Proceedings of the University of Nottingham 43rd Easter School, 15-18 April, 1985, pp. 135-159 [P. J. Buttery, N. B. Haynes and D. B. Lindsay, editors]. London: Butterworths.

Holder, A. T., Aston, R., Preece, M. A. \& Ivanyi, J. (1985). Journal of Endocrinology 107, R9-R12.

Johnsson, I. D., Butler-Hogg, B. W., Hathorn, D. J. \& Wilde, R. (1986). Animal Production 42, 433.

Johnsson, I. D. \& Hart, I. C. (1987). In Proceedings of the Twentieth University of Nottingham Feed Manufacturers Conference, 5-7 January 1986. London: Butterworths (In the Press).

Johnsson, I. D., Hart, I. C., \& Butler-Hogg, B. W. (1985). Animal Production 41, $207-217$.

Keshet, E., Rosner, A., Bernstein, Y., Gorecki, M. \& Aviv, H. (1981). Nucleic Acid Research 9, 19-30.

Kotts, C. E., \& Baile, C. A. (1985). Federation Proceedings 44, 484.

Kronfeld, D. \& Chalupa, W. (1986). Proceedings of California Animal Nutrition Conference March 5-6, Fresno, pp. 83-89.

McDonald, B. J., Waters, M. J., Richards, M. D., Thorburn, G. D. \& Hopkins, P. S. (1983). Research in Veterinary Science 35, 91-99.

Machlin, L. J. (1972). Journal of Animal Science 35, 794-800.

Martial, J. A., Hallewell, R. A., Baxter, J. D. \& Goodman, H. M. (1979). Science 205, 602-607.

Miller, W. L. \& Eberhardt, N. L. (1983). Endocrine Reviews 4, 97-130.

Miller, W. L., Martial, J. A. \& Baxter, J. D. (1980). Journal of Biological Chemistry 225, 7521-7524.

Miozzari, G. F. (1981). In Insulin, Growth Hormone and Recombinant DNA Technology, pp. 13-31 [J. L. Gueriguian, editor]. New York: Raven Press.

Moore, G. P. M., Panaretto, B. A. \& Robertson, D. (1982). Australian Journal of Biological Sciences 35, $163-172$.

Muir, L. A., Wien, S., Duqueth, P. F., Rickes, E. L. \& Cordes, E. H. (1983). Journal of Animal Science 56, 1315-1323.

Palmiter, R. D., Brinster, R. L., Hammer, R. E., Trumbauer, M. E., Rosenfeld, M. G., Birnberg, N. C. \& Evans, R. M. (1982). Nature 300, 611-615.

Panganiban, A. T. (1985). Cell 42, 5-6.

Peel, C. J., Bauman, D. E., Gorewit, R. C. \& Sniffen, C. J. (1981). Journal of Nutrition 111, 1662-1671.

Peel, C. J., Fronk, T. J., Bauman, D. E. \& Gorewit, R. C. (1983). Journal of Dairy Science 66, 776-782.

Pullar, R. A., Johnsson, I. D., Chadwick, P. M. C. \& Hart, I. C. (1986). Animal Production 42, 433-434.

Radke, K. \& Lagarias, D. (1986). Biotechnology 4, 4.

Rebhun, J. F., Etherton, T. D., Wiggins, J. P., Chung, C. S., Walton, P. E. \& Steele, N. (1985). Journal of Animal Science 61, Suppl. 1, 251. 
Rosenfeld, R. B., Wilson, D. M., Dollar, L. A., Bennett, A. \& Hintz, R. L. (1982). Journal of Clinical Endocrinology and Metabolism 54, 1033-1038.

Schalch, D., Reissman, D. F., Ember, C., Humbel, R., Li, C. H., Peters, M. \& Lau, E. (1984). Endocrinology 115, 2490-2492.

Schoenle, E., Zapf, J., Humbel, R. E. \& Froesch, E. R. (1982). Nature 296, 252-253.

Schwartz, J. \& Foster, C. M. (1986). Journal of Clinical Endocrinology and Metabolism 62, 791-794.

Seeburg, P. H., Shine, J., Martial, J. A., Baxter, J. D. \& Goodman, H. M. (1977). Nature $270,486-494$.

Seeburg, P. H., Shine, J., Martial, J. A., Ivarie, R. D., Morris, J. A., Ullrich, A., Baxter, J. D. \& Goodman, H. M. (1978). Nature 276, 795-798.

Skottner, A., Clark, R. G., Forsman, A., Fryklund, L. \& Robinson, I. C. A. F. (1985). Acta Endocrinologica $109,145$.

Smith, J., Cook, E., Fotheringham, I., Phebys, S., Derbyshire, R., Eaton, M. A. W., Doel, M., Lilley, D. M. J., Pardon, J. F., Patel, T., Lewis, H. \& Bell, L. D. (1982). Nucleic Acid Research 10, 4467-4482.

Souza, L. M., Boone, T. C., Murdock, D., Langley, K., Wypych, J., Fenton, D., Johnson, S., Lai, P. H., Everett, R., Hsu, R.-Y. \& Bosselman, R. (1984). Journal of Experimental Zoology 232, $465-473$.

Stebbing, N., Olson, K., Lin, N., Harkins, R. N., Snider, C., Ross, M. J., Fields, F., May, L., Fenno, J., Fodge, D. \& Prender, G. (1981). In Insulin, Growth Hormone and Recombinant DNA Technology, pp. 117-132 [J. L. Gueriguian, editor]. New York: Raven Press.

van Buul, S. \& van den Brande, J. L. (1979). Acta Endocrinologica 92, 242-257.

Veldhuis, J. D. \& Demens, L. M. (1985). Biochemical and Biophysical Research Communications 130, 234-240.

Wagner, J. F. \& Veeinhuizen, E. L. (1978). Journal of Animal Science 45, Suppl. 1, 397.

Wagner, T. E. (1985). Canadian Journal of Animal Science 65, 539-552.

Wagner, T. E., Murray, F. A., Minhas, B. \& Kraemer, D. C. (1984). Theriogenology 21, $29-44$.

Wallis, M., Howell, S. L. \& Taylor, K. W. (1985). The Biochemistry of Polypeptide Hormones, pp. $434-463$. New York: John Wiley.

Wolfrom, G. W. \& Ivy, R. E. (1985). Journal of Animal Science 61, Suppl. 1, 249-250.

Wolfrom, G. W., Ivy, R. E. \& Baldwin, C. D. (1986). Journal of Animal Science 61, Suppl. 1, 249. 